\title{
Fungus diseases of cultivated arctic bramble (Rubus arcticus L.) in Finland
}

\author{
ANNA-LIISA RUOKOLA \\ University of Helsinki, Department of Plant Pathology, SF-00710 Helsinki 71
}

\footnotetext{
Abstract. During 1975 and 1977-1979 studies were carried out on the fungus diseases of experimentally cultivated arctic bramble (Rubus arcticus L.).

The most common pathogenic or weakly pathogenic fungi isolated from the diseased clones were Cylindrocarpon destructans (Zins.) Scholten and Fusarium avenaceum (Cda ex Fr.) Sacc. Some other Fusarium species and Botytis cinerea Pers. ex Fr. were rather uncommon.

Didymella applanata (Niessl) Sacc. and plenty of pycnidia of Pboma spp. were established on nearly withered clones; among the isolates were $P$. exigua Desm. var. exigua Maas, Phoma spp. and Coniothyrium fuckelii Sacc. (con. st. of Leptosphaeria coniotbyrium (Fuck.) Sacc.).

Isolates of little significance were identified in the whole from 26 fungal genera.
}

\section{Introduction}

The distribution area of arctic bramble (Rubus arcticus L.), which comprises the whole of subarctic Eurasia, is bounded in Europe by the Scandinavian countries and Finland. According to RYYNÄNEN (1973), in Finland arctic bramble mainly bears fruit only in the zone which starts in ESE Finland and extends across the central part of the country to North Ostrobothnia. As a result of increasingly mechanized farming, the fruiting of wild $R$. arcticus, has become even more infrequent in Finland. Owing to the fine flavour of its berries, arctic bramble is much in demand, for instance for liqueur manufacturing.

The cultivation of arctic bramble was successfully carried out in Sweden already by LINNÉ (LINNAEUS 1762, ref. RYYNÄNEN 1973). In Finland, Salminen started experimental cultivation of this plant at the North Savo Experimental Station at Maaninka in 1933. Although the studies were interrupted during the second world war, they were continued again in 1960. At the present time, the experimental cultivation of $R$. arcticus has been centralized at the South Savo Experimental Station near Mikkeli and at the Institute of Horticulture at Piikkiö, both belonging to the Agricultural Research Centre. In addition to Piikkiö, the breeding of $R$. arcticus is also carried out at the Plant Breeding Department of Helsinki University, at Viikki. Breeding is based on the selection of wild arctic bramble clones and the 
crossing of these clones, and on the crossing of $R$. arcticus with its closely related $R$. ideaeus L. and $R$. stellatus Sm. (HIIRSALMI and SÄKÖ 1980).

Little attention has been paid to the possible contribution of fungal diseases to the problems associated with the cultivation of arctic bramble uptil now. RAUHALA (1958) has found some rust fungus species on wild $R$. arcticus.

Material and methods

The material used in investigating the healthiness of $R$. arcticus was collected in 1975 and 1977 from the arctic bramble cultivation trials located at the South Savo Experimental Station and from the breeding material of the Plant Breeding Department in 1977 and 1979.

Samples were taken from all vegetative parts of $R$. arcticus clones, from lightly diseased to almost completely damaged ones, in an exceptional case also from the soil around the roots of a withering clone. A total of 190 transfers from 20 clones were made to the nutrient media, mainly from the stem, expecially from the base of the stem. The fungi were usually cultivated on potato dextrose (PDA, Difco) and corn meal (CMA, Difco) agars containing 100 or $300 \mathrm{ppm}$ of streptomycin in 11 agar. Pieces of infected tissue were surface-sterilized of $2 \mathrm{~min}$ in $0.5 \% \mathrm{NaClO}$ and then rinsed with $94 \%$ ethanol and allowed to dry. The fungal cultures were incubated at a temperature of $23-25^{\circ} \mathrm{C}$. The fungi were photographed on malt extract (MA, Difco) agar.

\section{Results}

In the samples collected at Mikkeli in 1975, the highest proportion of pathogenic fungi were found on the base of the stem, Fusarium fungi being the most common ones (Table 1). Cylindrocarpon destructans, which is known to be a weak root pathogen (DOMSCH and GAMS 1970), was isolated from the base and root samples.

Fungi isolated from R. arcticus in 1975, 1977 and 1979, which occurred in more than $2 \%$ of the transfers, are shown in Table 2. C. destructans was the most

Table 1. The most important fungi isolated in 1975 from $R$. arcticus samples and the number of isolates. ( $)=$ no. of samples

\begin{tabular}{lccc}
\hline Fungus & Cane $(8)$ & Base of cane (10) & Root (9) \\
\hline Alternaria alternata & 1 & 1 & 0 \\
Coniotbyrium fuckelii & 1 & 0 & 0 \\
Cylindrocarpon destructans & 0 & 3 & 3 \\
Fusarium avenaceum & 2 & 6 & 2 \\
F. oxysporum & 0 & 2 & 2 \\
F. spp. & 3 & 4 & 1 \\
Pboma sp. & 0 & 0 & 1 \\
Total & 7 & 16 & 9
\end{tabular}


Table 2. The commonest fungal species, found in stands of $R$. arcticus, the number of isolates and the percentage of transfers in which the fungus occurred

\begin{tabular}{lrr}
\hline Fungus & No. & $\%$ \\
\hline Alternaria alternata (Fr.) Keissl. & 47 & 24.7 \\
Botrytis cinerea Pers. ex Fr. & 4 & 2.1 \\
Cladosporium spp. & 11 & 5.7 \\
Coniotbyrium fuckelii Sacc. (st.con. of Leptospbaeria & & \\
$\quad$ coniotbyrium (Fuck.) Sacc. & 76 & 3.1 \\
Cylindrocarpon destructans (Zins.) Scholten & 25 & 13.2 \\
Fusarium spp. & 32 & 16.8 \\
Gliodladium spp. & 7 & 3.6 \\
Mucor spp. & -74 & 23.1 \\
Penicillium spp. & 13 & 6.8 \\
Pbialopbora sp. & 13 & 6.8 \\
Phoma spp. & 17 & 8.9 \\
Trichoderma viride Pers. ex Fr. & 13 & 6.8 \\
Ulodadium consortiale (Thüm.) Simm. & 25 & 13.1 \\
Total & 257 & \\
\hline
\end{tabular}

*) one isolate from soil associated with roots

**) 3 isolates from soil associated with roots

common of the pathogenic fungi; it occurred in $33.3 \%$ of the root samples, representing $15.8 \%$ of all the transfers. The second most common were Fusarium species, of which $F$. avenaceum ( $\mathrm{Cda}$ ex $\mathrm{Fr}$.) Sacc. was found as frequently as the combined number of other Fusarium species, such as F. oxysporum Schl. emend Sn. \& Hans., F. culmorum (W. G. Sm.) Sacc., F. poae (Peck) Wollenw. and Fusarium spp. Phoma fungi (Fig. 1) were isolated, for instance, from one diseased bud and from one almost completely withered clone, the epidermis of which was slightly loose. In both of these cases, pseudothecia and ascospores of Didymella applanata (Niessl)

Fig. 1. Pboma spp. Pycnidia on the cane of $R$. arcticus. $10 \mathrm{x}$.

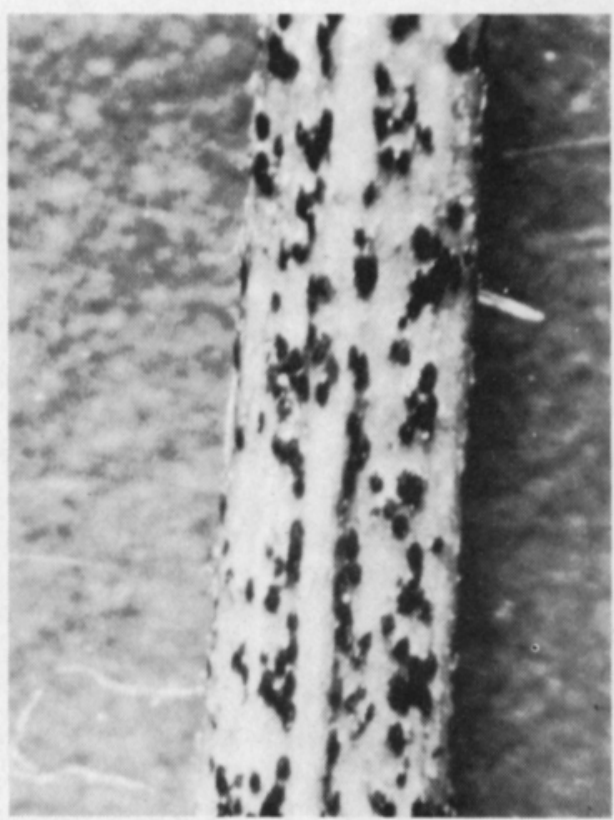




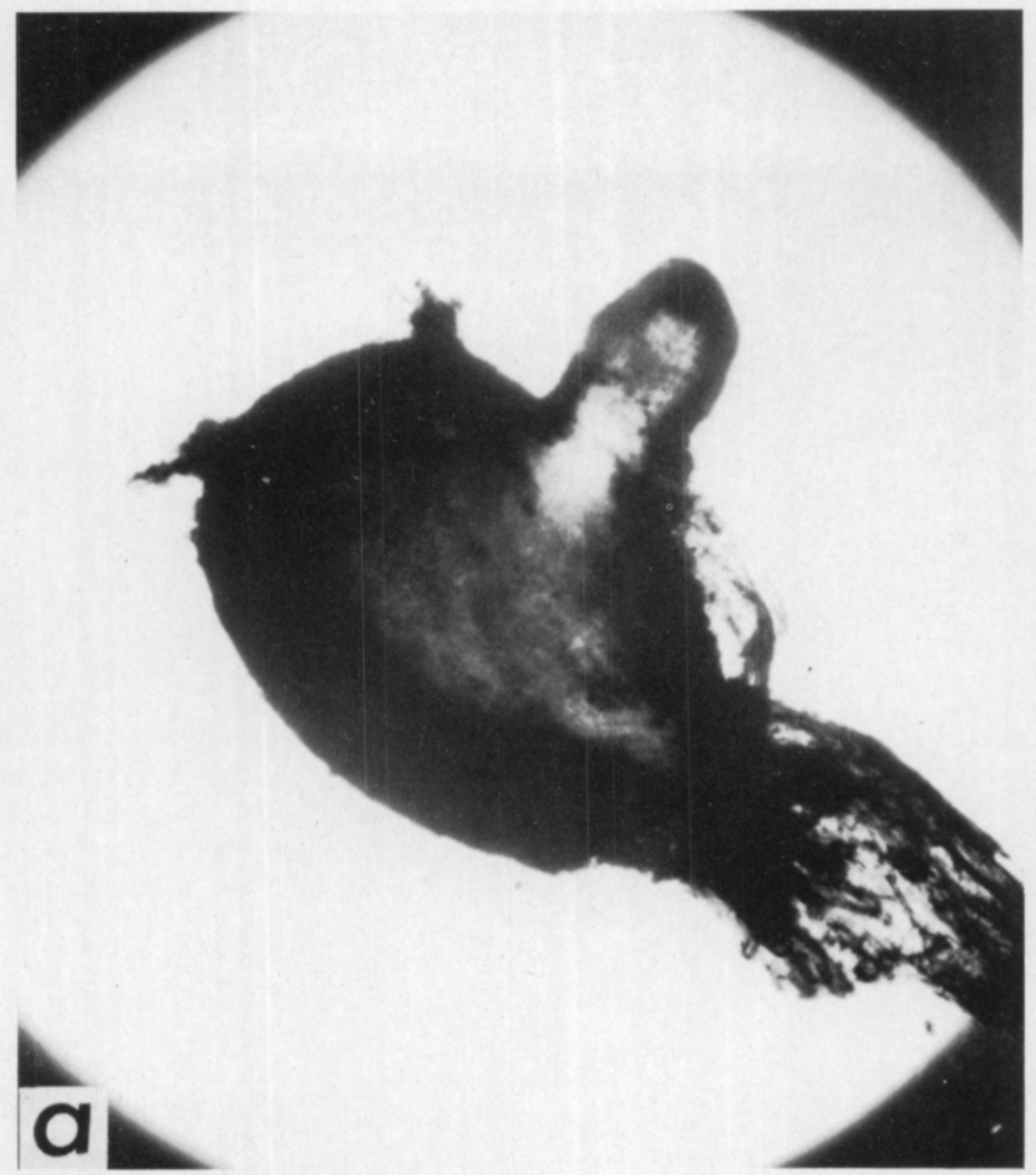

Fig. 2 a. Didymella applanata. Pseudothecium. 60 x.

Sacc. (Fig. 2 a, b) (cf. KOCH 1931), the causal agent of spur blight of raspberry, were evident. The perfect stage of the fungus did not grow on the nutrient medium. P. exigua Desm. var. exigua Maas was identified among the Phoma isolates. In addition to microscopic examinations (BOEREMA 1976), identification was also carried out by the colour reaction method recommended by BOEREMA and HÖWELER (1967).

Other fungi, mainly saprophytic ones, whose frequency was below $2 \%$, were also isolated from the stands of $R$. arcticus: Absidia sp., Acremonium sp., Aspergillus niger v. Tiegh., Chaetomium globosum Kunze ex Fr., Epicoccum nigrum Link, Fusidium sp., Helminthosporium sativum Pamm., King \& Bakke, Mortierella sp., Myrothecium verrucaria Ditmar ex Fr., Papulaspora sp., Phoma eupyrena Sacc., Podospora minuta (Fuck.) Winter, Sclerotinia sp., Septonema sp., Sordaria inaequalis Cain (CAIN and 


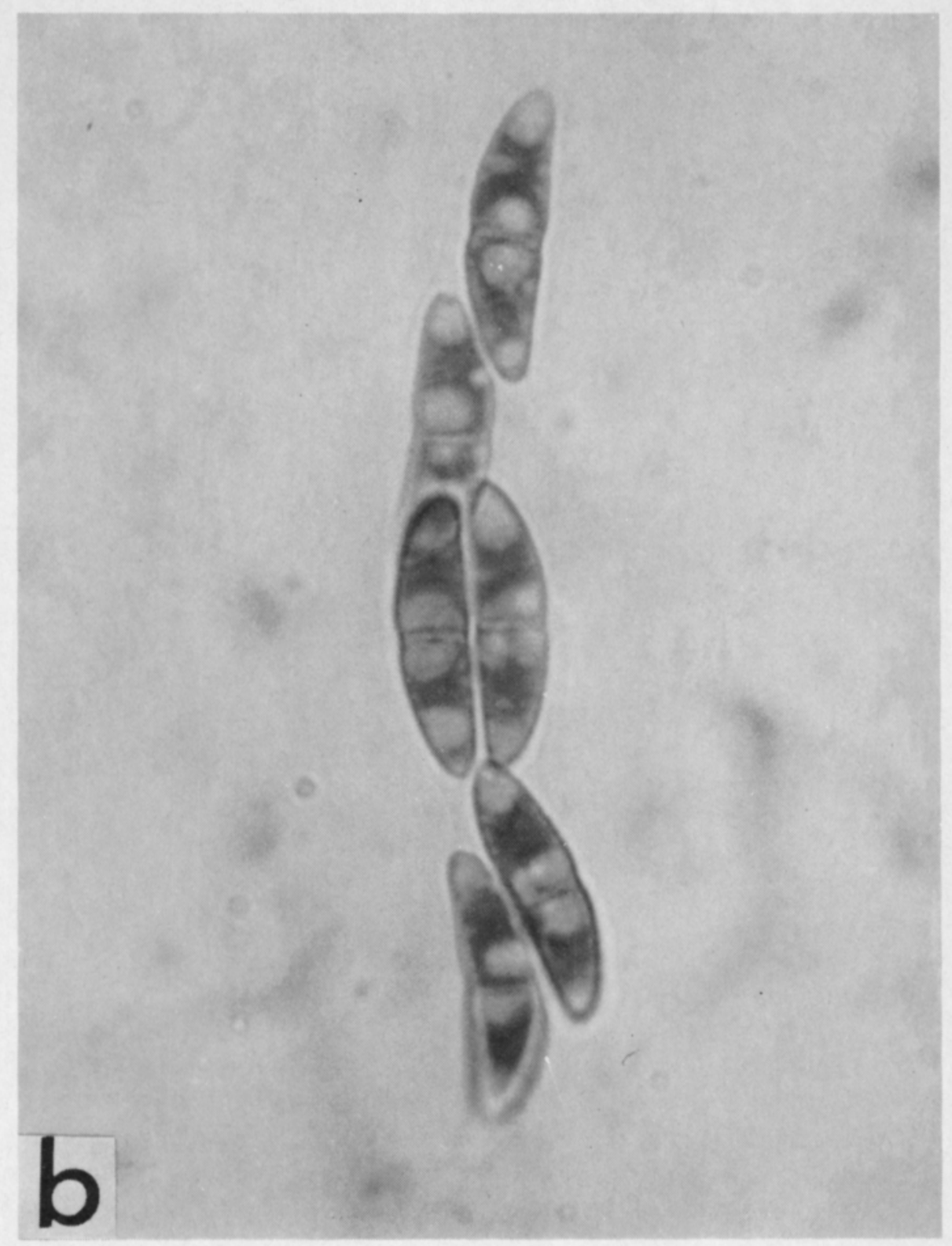

Fig. 2 b. D. applanata Ascospores. $650 \mathrm{x}$.

GROVES 1948), S. macrospora Auersw., Sporormia intermedia Auersw. (cf. DENNIS 1968) and Torula sp.

The following plant pathogens, in addition to the usual saprophytic fungi, were found in the dilution series (cf. NIENHAUS 1969) prepared from the soil, where the heavily infected clone was growing: Coniotbyrium fuckelii (Fig. 2 b), F. oxysporum and Truncatella truncata (Lév.) Stey. A heavy infection of powdery mildew, which was not presiously identified, was found on one of the $R$. arcticus clones in summer 1980. 


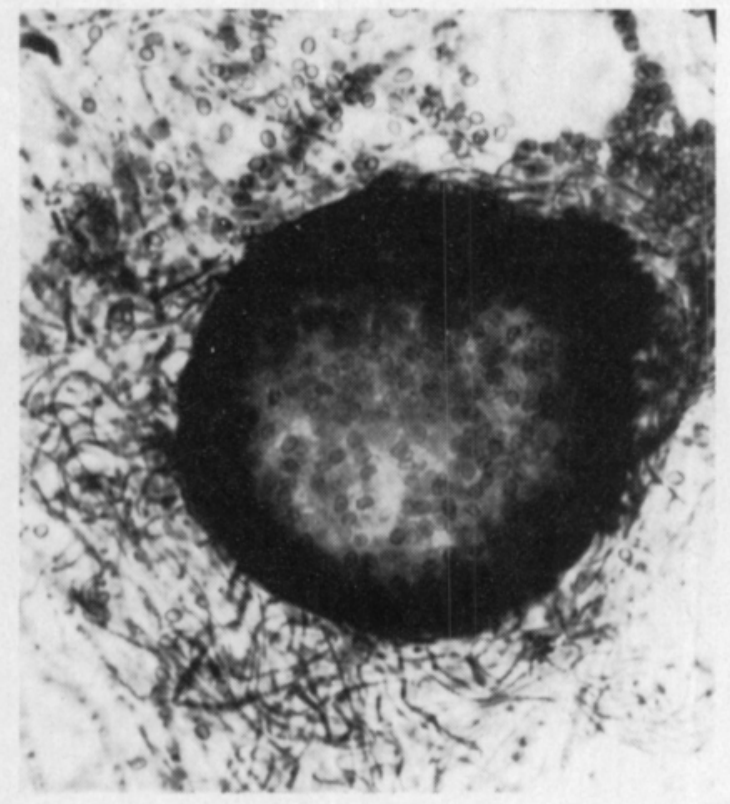

Fig. 3. Coniotbyrium fuckelii, Pycnidium and pycnospores after 10 days' frowth on MA. $100 \mathrm{x}$.

Inoclulation experiments were performed with selected fungal isolates in the greenhouse, but they were not successful since the clones of arctic bramble did not grow well in greenhouse conditions.

\section{Discussion}

The results show that cultivated $R$. arcticus is quite clearly susceptible to the same pathogens as its related plant, raspberry $(R$. ideaeus). According to SEEMÜLLER (1974), of 14 fungal species tested only Leptosphaeria coniothyrium was strongly pathogenic to raspberry, while, for instance, D. applanata, P. exigua var. exigua, Botrytis cinerea and $F$. avenaceum were only weakly pathogenic. However, in his study the degree of infection was found to be dependent on the wounding of the canes and on the point of inoculation. L. coniotbyrium was rather uncommon on the $R$. arcticus samples studied here; it was isolated from the canes, from one injured bud and from the soil around withering clone, where, together with $D$. applanata, it was probably the main reason for the damage to the plant.

According to KOCH (1931), as well as to the observations made in the present study, D. applanata is also quite common on wild raspberries. Transfer of this fungus to $R$. arcticus has not been examined. It has been established (JARVIS and HARGREAVES 1972) that $F$. avenaceum is probably the most important causative agent of raspberry lateral wilt in Scotland. In the present study $F$. avenaceum occurred in $7.9 \%$ of the transfers, most of them originating from the stem base.

\section{Acknowledgements}

I am greatly indebted to Dr. Risto Tahvonen for placing his fungal material isolated from $R$. arcticus in 1975 at my disposal. I also wish to express my gratitude to Dr. Annikki Ryynänen and to Phil.Lic. Jussi Tammisola for their help in collecting the material for my study. 


\section{References}

BOeremA, G. H. 1976. The Pboma species studied in culture by Dr. R.W.G. Dennis. Trans. Brit. Mycol. Soc. 67: 289-319.

- \& HÖWELER, L. H. 1967. Phoma exigua Desm. and its varieties. Persoonia 5: 15-28.

CAIN, R. F. \& GROVES, J. W. 1948. Notes on seed-borne fungi. VI. Sordaria. Canad. J. Res. C. 26: 486495.

DENNIS, R. W. G. 1968. British Ascomycetes. 455 p. Stuttgart.

DOMSCH, K. H. \& GAMS, W. 1970. Pilze aus Agrarböden. 222 p. Stuttgart.

HIIRSALMI, H. \& SÄKÖ, J. 1980. Hybrids of the arctic bramble species (Rubus stellatus $\times$ R. arcticus). Acta Hort. 112: 103-108.

JARVIS, W. R. \& HARGREAVES, A. J. 1972. Raspberry lateral wilt associated with Fusarium avenaceum. New or uncommon plant diseases and pests. Pl. Path. 21: 48.

KOCH, L. W. 1931. Spur blight of raspberries in Ontario caused by Didymella applanata. Phytopath 21: 247-287.

LINNAEUS, C. 1762. Ảkerbärs plantering. Kongl. Vet. Acad. Handl. 23: 192-197. (Ref. Ryynänen, A. 1973.)

NIENHAUS, F. 1969. Phytopathologisches Praktikum. 167 p. Berlin und Hamburg.

RAUHALA, A. 1958. Kasvien sienitauteja. 354 p. Porvoo-Helsinki.

RYYNÄNEN, A. 1973. Rubus arcticus L. and its cultivation. Ann. Agric. Fenn. 12: 1-76.

SEEMÜLLER, E. 1974. Infektiosität und Pathogenität verschiedener Pilze an Himbeerruten. Phytopath. Z. 80: $340-354$.

Ms received February 18, 1981.

\section{SELOSTUS}

\section{Viljellyn mesimarjan (Rubus arcticus L.) sienitaudit Suomessa}

\section{Anna-Liisa Ruokola}

Helsingin yliopiston kasvipatologian laitos, 00710 Helsinki 71

Vuosina 1975 ja 1977-1979 suoritettiin tutkimuksia koeviljellyssä mesimarjassa (Rubus arcticus L.) esiintyvistä sienitaudeista.

Lievästi lakastumis- tai tyvitautisista klooneista eristetyistä sienipatogeeneista olivat yleisimmät Cylindrocarpon destructans (Zins.) Scholten ja Fusarium avenaceum (Cda ex Fr.) Sacc. Eräät muut Fusarium-lajit sekä Botrytis cinerea Pers. ex Fr. olivat harvinaisia.

Lähes kuihtuneissa klooneissa todettiin Didymella applanata (Niessl) Sacc. sekä runsaasti Pboma-sienen pyknidioita; isolaattien joukossa oli P. exigua Desm. var. exigua Maas, Phoma spp. sacc. sekä Coniotbyrium fuckelii (perf. a. Leptosphaeria coniotbyrium (Fuck.) Sacc.).

Lisäksi eristettiin sieniä, kaikkiaan 26 eri sienisukuun kuuluvia, joiden merkitys ilmeisesti jäi vähäiseksi. 